\title{
The Model Development of Internet-Based In-House Training for Kindergarten Teachers in Bogor, Indonesia
}

\author{
Farida Wulandari $^{1}$, Billy Tunas ${ }^{2}$, Rita Retnowati ${ }^{3}$ \\ Post Graduate Program, Universitas Pakuan Bogor, Indonesia
}

\begin{abstract}
This research was triggered by the arising problem in kindergarten teachers whose low teaching capability as the result of lack training caused by factors such as teachers do not have the funds to pay for the training, the school does not provide training facilities due to lack of school budget, as well as the difficulty of getting teacher training opportunities provided by the government. Besides, the teachers do not use the internet facility on their hand-phone to seek knowledge effectively. Hand-phone is used only for communication. To solve this problem it is necessary to develop a model of internet-based in-house training as an alternative effort in organizing effective and efficient in-house training to develop teaching skills. Based on the findings of the study, an internet based in-house training model is recommended. The design model consists of input, process and output. Output of the model development of internet based in-house training is proven to increase the ability of kindergarten teachers in organizing in-house training and developing teaching capabilities.
\end{abstract}

Keywords: Model Development, Internet-Based In-House Training, Teachers

\section{INTRODUCTION}

Conditions in which teachers show low performance will eventually lead the school to be low quality as well. Therefore, schools generally provide training to teachers as a solution to improve their performance. Training program is a process of teaching certain knowledge and attitudes so that teachers' skill are increasing and able to carry out their responsibilities properly in accordance with the standards determined by the school. Training can be given by calling an expert in the field of science that is needed in the school's internal training or by sending some teachers to a training program organized by outside parties. The second in organizing the training course will require a special fund to be borne by the school.

The technology used at a school has close links to the various school characteristics such as the qualifications of teachers and school organizational structure. The use of Internet technology in schools is also associated with the competitive edge to improve the quality of information in monitoring school performance. Teaching skills developed by the school constantly want to improve the skills of teachers in schools. This is done to overcome learning disabilities and clearly understand the threat, as well as trying to identify new opportunities for the betterment of the school. Ability to teach will be achieved if there is support from the school principal. School leadership becomes the determinant factor for the competitive advantage of a kindergarten. Team learning should be built in schools because schools operate based on teamwork, which means the school cannot learn if all components in the school do not learn together. Sharing insights and knowledge in school are important in order to increase the school's capacity to augment the intellectual capital. In-house training programs for teachers conducted by the school is a platform of program in increasing human resource capability.

A kindergarten is an organization engaged in the field of early childhood education. Early childhood is a golden age where during this period is the best time in the stimulation to the children. Therefore, the kindergarten should be the most important part in providing intellectual stimulation to children. Kindergarten teacher should have the ability to achieve the goal of kindergarten teaching. However, the need for a teacher training program becomes a priority because there are few kindergartens that implement long learning concept in which the aspects of reading, math, and writing became the main target priority in development of students. 
Ironically, in the respective schools, the development of technology that offers a range of advantages of are not used to the maximum by the kindergarten teachers. They have personal cell phone, but is only used for communication. They also had complementary internet facilities in the handset, in order to get the facility to communicate using Facebook. But rarely do they take advantage of google to find information and knowledge related to the ability of teaching and learning in the classroom. Awareness to find information and knowledge on google, or technically not know how to operate google become an obstacle in the use of internet facilities optimally.

Model of Internet-based in-house training could eventually develop the ability to teach independently because the concept is to condition the teachers for independent study, to discuss and to work together in a team in order to seek knowledge continuously by using internet technology. As such, the problem is formulated as follows:

1. Is Internet based in-house training model can enhance the skills of teachers of kindergarten in organizing in-house training as an effort to develop teaching skills?

2. How Internet based in-house training model centre can improve the skills of teachers of Kindergarten in organizing in-house training as an effort to develop teaching skills?

\section{RESEARCH METHODOLOGY}

In this study, it was conducted a few experiments of in-house training activities performed by teachers as forms of trial aimed at determining whether the model of Internet based in-house training can enhance the ability of teachers of kindergarten in organizing an independent in-house training. By organizing this type of training, it can also be shown the extent to which teachers get other benefits, such as; how teachers develop their personal mastery, being the presenter, adapting at using the Internet, conducting independent study as well as studying and discussing in the group (team learning).

This type of research is the development model that refers to the theories of Borg \& Gall (2005) as the research stages systematically help the way in the development of new models that can strengthen this model as a model of in-house training for kindergarten teachers. This is possible because the study is based on the review of theory and field, then do limited testing and more extensive trials, and tested again through the validation process in 8 (eight) kindergartens located in Bogor, West Java, Indonesia. The method used in this study is a survey method, formative evaluative research, and experimentation.

Step-by-step development of the model refers to a review of theory and field, then limited testing and extensive trials are performed and tested through a validation process by expert's judgment. A review is carried out on the model and the impact of the development models on the ability of kindergarten teachers in organizing in-house training. Based on the review of theory and observation, then the model generates the following steps:

1. School serve as organizers of internet-based in-house training on where the principal as a person in charge of the program. Participants and presenters are teachers who teach at the kindergarten.

2. Implementation of in-house training is done every week at the school after school hours when the class hours end.

3. The material source is obtained from the internet.

4. Management of in-house training.

After the implementation of the pilot project in three kindergartens as well as the findings in discussions with experts for the model, experts for in-house training and teaching skills, experts for kindergarten education, then the final model generates the following some inputs respectively:

- it is needed clear advice from teachers to determine the topics raised for presentation.

- conclusions are proceeded with the testimony of teachers or teacher journals.

- in-house training outcomes should build concept with the characteristic of enforcement forcing the teachers to make the activity as culture and habit forming.

All experts conclude that the modules for the program has been well-designed. 


\section{RESULT AND DISCUSSION}

From the results of the Delphi technique, the recommended model is described as a model of in-house training to improve knowledge of kindergarten teachers on effective teaching in the classroom where they get this knowledge from the internet. This model impacted on their mastery of personal development, such as independent study, as the presenter, capable of becoming a presenter, as well as groups discussion to find a solution together (team learning) on what effective learning is with the following elaborated steps:

1. Schools serve as organizers of in-house training where the principal acts as a person in charge of the program. Participants and presenters are teachers who teach at the kindergarten.

2. Implementation of in-house training is done every week at the school after school hours in the class end.

3. The material is obtained from the internet.

4. Management of in-house training in terms of planning, organizing, implementing and monitoring and finally evaluating and analyzing.

a. planning

1) analyzing needs; specifying material and support equipment as well as training methods.

2) studying of literature via the internet.

3 ) ing that teachers have the motivation and ability to master basic training.

4) discussing whether training sessions have factors that are necessary for learning to happen.

5) setting up training support equipment, such as; mobile phone / computer, internet modem.

b. organizing

1) principal designates one teacher to become a presenter.

2) presenter finds the source of the material on the internet and records it in order to be used as information reference during presentation.

3) presenter learns the material before presenting in front of the participants.

4) principal fills in observation sheet on the ability of teachers and the provision of in-house training

c. implementing and monitoring

1) presenter gives exposure.

2) discussion / peer-teaching.

3) frequently asked questions.

4) principal monitors the implementation of the program.

d. evaluating and analyzing

1) evaluation of the results of observation.

2) evaluation of program management.

3) analysis of the achievement of program delivery capability.

The result indicates that the model of Internet based in-house training proved improves kindergarten teachers' knowledge in teaching and solving problems in the classroom effectively beside personal mastery of teachers are formed in terms of independent study, becoming the presenter, using the internet, as well as group discussion to find solutions together (team learning) through in-house training with internet-based.

\subsection{School's Competency to Organize In-House Training}

The ability of the five kindergartens in organizing in-house training is seen to rise from the first to the fourth stage. This indicates that the model of Internet Based In-House Training is easy to be 
implemented and applied by teachers at each school. The stages in the model effectively assist them in preparing the implementation of in-house training, discussion, concluding the topic of discussion, and evaluation of the in-house training. This achievement proves that the development model can become a recommended model and has a measurable instrument for the change to occur. Therefore, this model is able to assist principals and teachers in kindergarten to gain knowledge on effective learning and to solve problems efficiently by referring to the theories discussed which are easily accessible from the internet in hand phone or their laptop. This is consistent with the theory of Stuart A. Klugman (2012) in his book Loss Model that the model is built on the knowledge and experience combined with data obtained from previous experiences.

Internet Based In-House Training centre can be effectively organized by kindergarten because any discussion of the teachers can be used as a reference in teaching as well as to solve the problem of students and parents. This is consistent with what is stated by Mel Siberman (2005) in his book 101 Ways to Make Training Active, stating the success of any active training is measured by how the question is answerd, that is, how what has been learned in the course is transferred back on the job.

The development model of Internet Based In-House Training can become a recommended model because of its effectiveness as kindergarten may easily organize it. This effectiveness is obtained based on the number of times the action is evaluated and reflected. The stages of research and development are in accordance with the theory of Borg \& Gall (2005) stating that the method of systematic research and development can help the way in the development of new models and strengthen the new model as a good model.

\subsection{Ability of Teachers in Using the Internet}

The ability of teachers to use the internet in search of information on the topic in the in-house Internet-based training increased from the first to the fourth stage. This increase shows that the ability of teachers can be developed and enhanced through a continuous in-house training. This is consistent with the theory of Kaswan (2011) on the implementation of in-house training where Internet-based learning in training can change behavior permanently.

Internet Based In-House Training are part of an educational process that aims to improve the ability of a special person or group of people using the internet facility in the training process. Achievement of these capabilities is in accordance with what is stated by Tata Sutabri (2013), that the Human Resources Information System (HRIS) is a form of interaction between science of human resource management (HRM) and information technology. The system combines the disciplines of HRM as the application of information technology into HRM activities such as planning, preparation of data processing systems, recruitment and reception (recruitment and hiring), education and training as well as data management.

The technical capabilities of teachers in the use of internet facilities are significant changes in their professional teacher making as it is in accordance with the demands of technology-based education. This is consistent with the theory of Sutherland (2009) in his Improving Classroom Learning with ICT which stated that the model of professional development of teachers by using research through computer technology could develop teachers 'knowledge substantially. This affects the ability of teachers to improve students' learning ability.

\subsection{Teachers' Capability in Becoming Presenter}

Changes in capability from not able to be a presenter to be a presenter is an indication of changes in the quality of teachers. This happens because the school provides opportunities to all teachers in the school to be a presenter in Internet Based In-House Training conducted at the school independently and continuously. Schools that provide space and opportunity for teachers to build confidence in harmony with mental model theory The Fifth Discipline Peter Senge (1996) where the mental model is a process of reflection, continuous clarification and improving picture about ourselves outside the world, and see how they shape our decisions and actions. As a presenter at the Internet Based InHouse Training, the teacher is responsible for finding information on the internet showing the concept of high self-learning. Self-learning is crucial characteristic owned by a teacher because the teacher must be a learner, where this behavior can make a professional teacher and be a role-model for learners in the classroom. Presenter must perform some duties ranging from the search for the source of the material on the internet, record it in order to be used as reference information in making paper presentations, study material before presenting in front of the participants, as well as prepare the 
recording material, and paper presentations to foster abilities and traits broader soft skills such as; self-awareness to improve performance, adaptive, critical thinking, integrity, confidence, empathy, problem solving, and have good time management. This is consistent with the theory raised by Peggy Klaus (2007) training provision is fundamentally able to grow the capabilities and properties of soft skills.

\subsection{Teacher Participation in Attending In-House Training}

The ability of teachers to participate in the discussion increases from the first act to fourth stages. The increasement shows in the form of their participation where the principal and teachers build commitment in a group, develop a picture together about the future that will be created as well as teachers, students, and parents communicate and interact effectively and efficiently to achieve maximum student learning targets. It also signifies the participation in form of learning team where the principal and teachers transform the conversation and expertise. This is consistent with the theory of shared vision by Peter Senge (1996) to build a sense of commitment in a group, to develop a picture together about the future that will be created, principles and practices that guide how to achieve the future goals.

The principle implementation of the in-house Internet-based training is how teachers and principals change their perspectives and thoughts on how knowledge and skills can be achieved by actively participating in the discussion rather than through education or formal training. Changes take effect in getting new ideas, capabilities, and experience. By always being set in this condition, the teacher is able to undergo a change in individual and group thinking by discussing so that the results obtained will lead to thinking and understanding of the material on a larger scale. This is consistent with the theory of Howard Gardner (2004) in Changing Minds stating that the discussion is how people change their perspectives and thoughts on how knowledge and skills can be achieved through self study and discussion.

\section{CONClusion}

Based on the research findings, data analysis and reflection on each trial, that research and development R \& D (Research \& Development) produces recommended models namely the development model of the Internet Based In-House Training.

Schools serves as organizers of In-House Training Centre where the principal as a person in charge of the program. Participants and presenters are teachers who teach at the kindergarten. Implementation of in-house training is done every week at the school after school hours in end. The material is obtained from the internet.

Management of in-house training consists of planning, where the principal analyzes the needs; specifies material and support equipment and methods of training, literature study through the Internet. Furthermore, the principal must ensure that teachers have the motivation and ability to master basic training, discusses what factors needed for learning to happen, prepares training support equipment, such as; mobile phone / laptop, internet modem. Organizing is started from the principal designating one teacher to become a presenter, then the presenter looks for the source material in google, and records it in order to be used as reference information in presentations before presenting study material in front of the participants. After that the principal distributes observation sheet on the ability of teachers and the provision of in-house training. The third step is the implementation and monitoring the presenter's exposure in leading discussions as well as addressing question and answer. During discussion, the principal monitors the implementation of the program as well as evaluates and analyzes the achievement of program delivery.

\section{REFERENCES}

Borg, Gall. Educational Research: An Introduction Fifth Edition. New York: Longman. 2005.

Gardner, Howard. Changing Minds. Massachusetts: Harvard Business School Press, 2004

Kaswan. Pelatihan dan Pengembangan. Bandung: Alfabeta, 2011.

Klaus, Peggy. Soft Skills. Jakarta: IKAPI, 2007.

Klugman, S. A., Panjer, H. H., \& Willmot, G. E. (2012). Loss models: from data to decisions (Vol. 715). John Wiley \& Sons. 
Farida Wulandari et al.

Senge', Peter. Disiplin Kelima. Jakarta: Bina Rupa Aksara, 1996.

Silberman, Mel. 101 Ways to Make Training Active. San Fransisco: Pfeiffer, 2005.

Sutherland, Rosamund. Improving Classroom Learning with ICT. London \& New York: Routledge. 2009.

Tata Sutabri. Komputer dan Masyarakat. Yogyakarta: Penerbit Andi, 2013 